ORIGINAL ARTICLE

\title{
Angiotensin converting enzyme activity in infancy is related to birth weight
}

\author{
J S Forsyth, J Reilly, C G Fraser, A D Struthers
}

Arch Dis Child Fetal Neonatal Ed 2004;89:F442-F444. doi: 10.1136/adc.2003.027896

See end of article for authors' affiliations

\section{Correspondence to:}

Professor Forsyth, Tayside

Institute for Child Health,

University of Dundee,

Scotland, UK; i.stewart.

forsyth@tuht.scot.nhs.uk

Accepted 1 December 2003
Aims: (a) To measure infant angiotensin converting enzyme (ACE) activity in healthy term infants at birth and during the first three months of life. (b) To determine the relation between serum ACE activity and infant feeding practice during this period. (c) To investigate the relation between serum ACE activity and birth weight and other potential contributing factors including acid-base status at birth, gestation, and maternal ACE genotype.

Methods: Prospective study of term infants, with clinical and feeding data collected from parents and medical records, and serum ACE measured in the infant at birth and 1 and 3 months of age, and in the mother at the time of birth and one to three months after birth.

Results: At birth and 1 and 3 months of age, infant serum ACE activity was twice that of maternal ACE activity. Infant ACE activity at birth and 1 and 3 months did not significantly differ between breast and formula fed infants. There was a highly significant negative correlation between infant ACE activity at 3 months and birth weight $(r=-0.52 ; \mathrm{p}<0.001)$. This persisted after the conversion of birth weights to $z$ scores $(r=-0.34 ; p=0.03)$. ACE activity at 3 months was also related to placental weight $(r=-0.30$; $p=0.02)$ and maternal age $(r=-0.30 ; p=0.05)$. The strong correlation between serum ACE activity and birth weight $z$ score persisted after adjustment for maternal age and placental weight $(r=-0.34$; $\mathrm{p}=0.03$ ).

Conclusion: As ACE is increasingly identified as a risk factor for cardiovascular disease, serum ACE activity in infancy may contribute to the link between low birth weight and later cardiovascular events.
$\mathrm{T}$ here are numerous reports of low birth weight being associated with coronary heart disease, hypertension, stroke, and non-insulin dependent diabetes. ${ }^{1}$ These associations are thought to be the consequence of a stimulus or an insult occurring at a critical period of early life and resulting in permanent effects on structure and metabolism. ${ }^{2}$ There is evidence that this concept of "programming" may not be exclusive to intrauterine life, and nutritional interventions during the postnatal period may also influence later health. ${ }^{3}$ For example, recent data indicate that children who are breast fed in infancy have lower blood pressures during later childhood and adolescence than children who are formula fed. ${ }^{4-6}$ Although there are several constituents of breast milk that are possible causes, including hormones, nutrients, and trophic substances, ${ }^{5}$ the underlying mechanisms remain uncertain.

Angiotensin converting enzyme (ACE) not only has a key role in the regulation of peripheral blood pressure, ${ }^{7}$ but it is now increasingly being identified as a major risk factor for cardiovascular disease. ${ }^{89}$ There is some evidence that ACE activity may be increased in preterm infants especially those with respiratory distress syndrome in the newborn period..$^{10}{ }^{11}$ Infant lung capillaries are a rich source of ACE, and hypoxic mice are known to have raised serum ACE activity at birth. ${ }^{11}$ Whether this increased activity is related to lung immaturity or to other associated factors, including hypoxia ${ }^{12}$ and intrauterine growth, ${ }^{13}$ has not been determined. Moreover, it is not known whether raised ACE activities are sustained beyond the immediate newborn period.

There are no published data relating ACE activity to infant feeding practice. However, there is evidence that milk contains peptides that inhibit serum ACE activity. ${ }^{14}{ }^{15}$ The inhibitory effect of these peptides on ACE activity may be more obvious in breast fed infants as whey proteins have a strong inhibitory effect and these predominate in breast milk. Moreover, the intestinal flora of breast fed infants is dominated by bifidobacteria that traditionally ferment milk proteins into ACE inhibitory peptides.

The aims of this study were therefore to $(a)$ measure infant serum ACE activity in healthy term infants at birth and during the first 3 months of life, $(b)$ determine the relation between serum ACE activity and infant feeding practice during this period, and (c) investigate the relation between serum ACE activity and birth weight and other potential contributing factors including acid-base status at birth, gestation, and maternal ACE genotype.

\section{METHODS}

The infants were recruited to the study during the early postnatal period, after informed consent had been obtained from their mother or guardian. They were born at term (259294 days) and had already received their first breast or formula feed.

Clinical data were collected prospectively. These included placenta weight, gestation, mode of delivery, and birth weight. Infant feeding information included type of milk feed at birth and number of breast, formula, and solid feeds at 1 and 3 months of age. Maternal blood pressure was measured one to three months after delivery.

Umbilical cord blood was obtained immediately after birth to measure acid-base status and serum ACE activity. Capillary samples $(100 \mu \mathrm{l})$ were taken from the infant at $\mathrm{l}$ and 3 months of age to measure serum ACE activity. A venous blood sample was taken from the mother to determine ACE genotype and also to measure maternal ACE activity at birth and one to three months after delivery.

Serum ACE activity was measured by an automated technique that requires small volumes of blood $(100 \mu \mathrm{l})$. ACE was assayed by monitoring the change in absorbance at $340 \mathrm{~nm}$ caused by the hydrolysis of furylacryloyl-phenylalanylglycylglycine to furylacryloyl-phenylalanine and glycylglycine (Sigma Aldrich Chemical Co, Poole, Dorset, UK) on an 


\begin{tabular}{lc} 
Table 1 & Maternal and infant characteristics \\
\hline $\begin{array}{l}\text { Maternal age (years) } \\
\text { Maternal systolic blood }\end{array}$ & $29.0(6.8)$ \\
pressure & $11.1(6.5)$ \\
Maternal diastolic blood & $70.0(7.3)$ \\
pressure & \\
Delivery: spontaneous/ & $44 / 24$ \\
assisted & $281(8.7)$ \\
Gestation (days) & $3498(506)$ \\
Birth weight (g) & $668(138)$ \\
Placenta weight (g) & $7.31(0.07)$ \\
Umbilical cord pH & $-4.2(2.5)$ \\
Umbilical cord base excess & $44 / 24$ \\
Male/female & $39 / 29$ \\
Feed at birth: breast/ \\
formula
\end{tabular}

Hitachi 917 clinical chemistry system (Roche, Lewes, East Sussex, UK). ACE genotype was measured by standard techniques. ${ }^{16}$

Data were analysed using SPSS for Windows, version 10.1 (SPSS Inc, Chicago, Illinois, USA). Comparison between groups was analysed using Student's $t$ test, and effects of confounding variables were assessed by multiple regression analysis.

\section{RESULTS}

Sixty eight infants were recruited to the study. Table 1 shows the maternal and infant characteristics. No infant had a positive history of maternal hypertension, and there were no major neonatal problems. All infants started milk feeds within four hours of birth. Table 2 shows feeding details.

Table 3 shows the mean (SD) serum ACE activity for mothers at birth and one to three months after delivery, and the serum ACE activity in infants at birth and $l$ and 3 months of age. There were no significant differences between infant serum ACE activity at 1 and 3 months of age but both were significantly higher than at birth. There was also significantly more variance at 1 month of age than at birth and 3 months. At birth and 1-3 months, infant serum ACE activity was twice that of maternal serum ACE activity. Maternal ACE activity measured at the time of birth and at one to three months postnatal did not differ significantly. Maternal ACE activity correlated positively with maternal genotype (II, ID, DD) $(r=0.59 ; \mathrm{p}<0.01)$, but not with maternal blood pressure.

There was no significant difference in infant ACE activity at birth and 1 and 3 months of age between breast and formula fed infants (table 4 ). However, only $22 \%$ of infants were exclusively breast fed at 3 months.

Serum ACE activity at birth and 1 month of age was not related to birth weight, but there was a highly significant negative correlation between infant ACE activity at 3 months and birth weight $(r=-0.52 ; \mathrm{p}<0.001)$. This correlation persisted after the conversion of birth weights to $\mathrm{z}$ scores $(r=-0.34 ; \mathrm{p}=0.03 ;$ fig $\mathrm{l})$. ACE activity was also related to placental weight $(r=-0.30 ; \mathrm{p}=0.02)$ and maternal age $(r=-0.30 ; \mathrm{p}=0.05)$. The significant relation between

Table 2 Feeding characteristics

\begin{tabular}{llllll}
\hline & \multicolumn{3}{l}{$\begin{array}{l}\text { No of feeds/day at } \\
\mathbf{1} \text { month }\end{array}$} & & \multicolumn{2}{l}{$\begin{array}{l}\text { No of feeds/day at } \\
\mathbf{3} \text { months }\end{array}$} \\
\cline { 2 - 3 } \cline { 5 - 6 } Feed at birth & Breast & Formula & & Breast & Formula \\
\hline Breast & $5.4(4.6)$ & $3.0(3.7)$ & & $3.4(3.6)$ & $3.5(3.0)$ \\
Formula & $0.0(0.0)$ & $6.7(1.3)$ & & $0.0(0.0)$ & $5.3(1.1)$ \\
\hline Values are mean (SD). & & & & \\
\hline
\end{tabular}

Table 3 Maternal and infant angiotensin converting enzyme (ACE) activity (units/l)

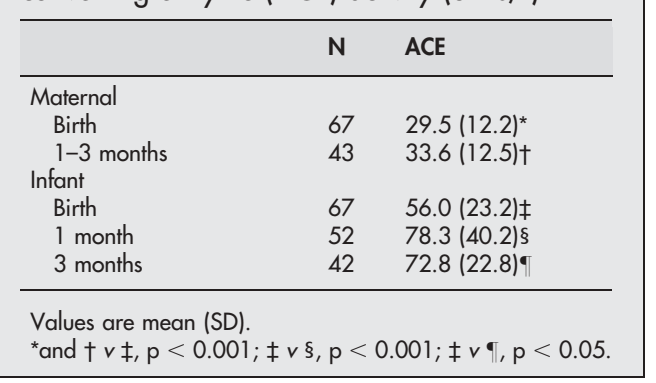

Table 4 Relation between feeding practice and infant angiotensin converting enzyme (ACE) activity (units/l)

\begin{tabular}{llll}
\hline \multirow{3}{*}{ Predominant feed } & ACE activity & \\
\cline { 2 - 4 } & Birth & $\mathbf{1}$ month & 3 months \\
\hline Breast milk & $55.0(15)^{*}$ & 83.0 & $70.2(22) \dagger$ \\
& $(n=21)$ & $(44) \dagger(n=21)$ & $(n=18)$ \\
Formula & $57.6(23)^{*}$ & $\begin{array}{l}75.1(37) \dagger \\
(n=31)\end{array}$ & $\begin{array}{l}74.8(23) \dagger \\
(n=24)\end{array}$ \\
\hline \multirow{2}{*}{$\begin{array}{llll}\text { Values are mean (SD). } \\
* v \dagger, p<0.05 .\end{array}$} & & \\
\end{tabular}

serum ACE activity at 3 months and birth weight $\mathrm{z}$ score persisted after adjustment for maternal age and placental weight $(r=-0.34 ; \mathrm{p}=0.03)$.

\section{DISCUSSION}

This study of healthy term infants shows that infant serum ACE activity at 3 months of age is related to size at birth but not to breast or formula feeding. A possible implication of these findings is that components of the renin-angiotensin pathway may be directly or indirectly linked to mechanisms that influence fetal growth.

Previous human data on ACE activity have been linked to specific pathological circumstances including maternal hypertension, ${ }^{13}$ prematurity, ${ }^{10}$ and infant respiratory ${ }^{11}$ and acid-base abnormalities. ${ }^{13}$ Moreover, measurements of serum ACE activity have been limited to the immediate newborn period. There are no published longitudinal data on healthy term infants and the relation of serum ACE activity to type of infant feeding. Recruits to this study were born at term after a normal pregnancy, they had normal acid-base status at birth, and there was no history of maternal hypertension. The data were therefore not confounded by factors that had

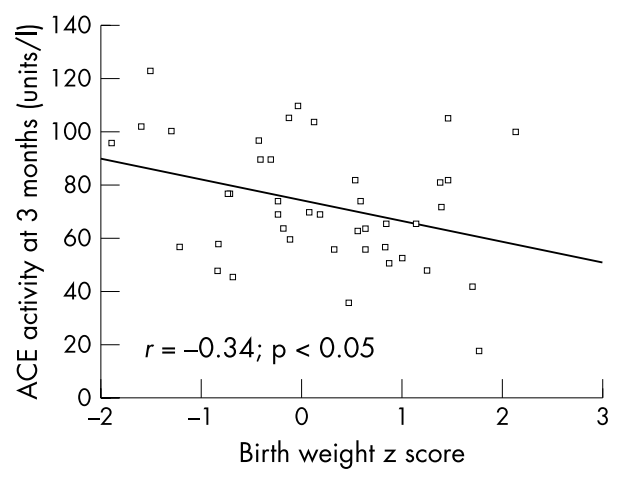

Figure 1 Correlation between infant angiotensin converting enzyme (ACE) activity at 3 months of age and birth weight after conversion into $z$ scores. 
previously been reported to be associated with raised infant serum ACE activity. Despite this relatively homogeneous study population, a significant correlation between birth weight and infant serum ACE concentration at 3 months of age was noted.

Previous studies have reported higher serum ACE activity in infants than adults. ${ }^{13}{ }^{17}$ It is known that lung endothelial cells are a rich source of circulating ACE and therefore the raised activities in infants may be related to rapid lung development that occurs during the last trimester and the immediate postpartum period. ${ }^{18}$ Several studies have indicated that serum ACE activities are higher in preterm infants, suggesting that ACE may be more active in the immature lung. ${ }^{17}$

The variance in ACE activity at 3 months of age was significantly less than that at birth and 1 month. Serum ACE activity at birth and 1 month of age was not related to weight at birth, but there was a highly significant negative correlation between infant ACE activity at 3 months and birth weight. This correlation persisted when the birth weights were converted into z scores. In this cohort of term infants, gestation was not independently related to ACE activity. The serum ACE activities at 3 months were therefore not only more stable, but they also related significantly to variation in birth weights within a narrow gestational range.

This strong association between birth weight and serum ACE suggests that ACE or the renin-aldosterone system may be linked to mechanisms controlling early human growth. ${ }^{19} 20$ There is laboratory evidence indicating that angiotensin II has a specific growth factor-like effect on target tissue, ${ }^{19}$ and it has been proposed that the renin-angiotensin system has a pivotal role in fetal development and growth. ${ }^{20}$ These data are supported by the adverse findings of growth retardation and pulmonary hypoplasia with ACE inhibitor medication when prescribed antenatally. ${ }^{21}$ It is therefore possible that the higher serum ACE activity in infants of lower birth weight may reflect a compensatory mechanism to achieve catch up growth after a period of faltering fetal growth.

Whether the increased serum ACE activities then have long term effects is not known, and it will be important to determine if serum ACE activity tracks into later childhood. As angiotensin II is the main metabolite of serum ACE activity, and as it has been shown to have atherogenic effects, ${ }^{89}$ increased serum ACE activity in early life could programme the individual for increased cardiovascular disease in later life.

\section{ACKNOWLEDGEMENTS}

We acknowledge the laboratory support from Lesley MacFarlane, Val Godfrey, and Andrew Cassidy, and initial project support from Karen Tosh.
Authors' affiliations

J S Forsyth, J Reilly, Tayside Institute for Child Health, University of Dundee, Scotland, UK

C G Fraser, Biochemical Medicine, University of Dundee

A D Struthers, Clinical Pharmacology and Therapeutics, University of Dundee

\section{REFERENCES}

1 Godfrey KM, Barker DJP. Fetal nutrition and adult disease. Am J Clin Nutr 2000;71:1344S-52S.

2 Lucas A. Programming by early nutrition in man. In: Bock GR, Whelan J, eds. The childhood environment and adult disease. Chichester: John Wiley and Sons, 1991:38-55.

3 Lucas A, Fewtrell MS, Cole TJ. Fetal origins of adult disease: the hypothesis revisited. BMJ 1999;319:245-9.

4 Wilson AC, Forsyth JS, Greene SA, et al. Relation of infant diet to childhood health: seven year follow up of cohort in Dundee infant feeding study. BMJ 1998;316:21-5.

5 Singhal A, Cole TJ, Lucas A. Early nutrition in preterm infants and later blood pressure: two cohorts after randomised trials. Lancet 2001;357:413-19.

6 Taittonen L, Nuutinen M, Turtinen J, et al. Prenatal and postnatal factors in predicting later blood pressure among children: cardiovascular risk in young Finns. Pediatr Res 1996:40:627-32.

7 Amiel SA. An ACE in the hole. Diabetic Medicine 1999;16:887-8.

8 Dahlof B, Devereux RB, Kjeldsen, et al. Cardiovascular morbidity and mortality in the LIFE study: a randomised trial against atenolol. Lancet 2002;359:995-1003.

9 Brunner H, Gavras H. Angiotensin blockade for hypertension: a promise fulfilled. Lancet 2002;359:990-2.

10 Bender JW, Davitt MK, Jose P. Angiotensin-I-converting enzyme activity in term and premature infants. Biol Neonate 1978;34:19-23.

11 Mattioli L, Zakheim M, Mullis K, et al. Angiotensin-l-converting enzyme activity in idiopathic respiratory distress syndrome of the newborn infant and in experimental alveolar hypoxia in mice. J Paediatr 1975;87:97-101.

12 Tetlow HJ, Broughton Pipkin F. The effect of changes in blood gas tension upon the renin-angiotensin system of the newborn infant. Br J Obstet Gynaecol 1983;90:898-903.

13 Broughton Pipkin F, Symonds EM. Factors affecting angiotensin II concentrations in the human infant at birth. Clin Sci Mol Med 1977;52:449-56.

14 FitzGerald RJ, Meisel H. Milk protein-derived peptide inhibitors of angiotensin-I-converting enzyme. Br J Nutr 2000;84(suppl 12):S33-7.

15 Mullally MM, O'Callaghan DM, FitzGerald RJ, et al. Proteolytic and peptiolytic activities in commercial pancreatic protease preparations and their relationship to some whey protein hydrolysate characteristics. J Agric Food Chem 1994:42:2973-81.

16 Shanmugam V, Sell KW, Saha BK. Mistyping ACE heterozygotes. PCR Methods and Applications 1993;3:120-1.

17 Walther T, Faber R, Maul B, et al. Fetal, neonatal cord, and maternal plasma concentrations of angiotensin-converting enzyme (ACE). Prenat Diagn 2002;22:111-13.

18 Pitt B, Lister G, Davies P, et al. Correlation of pulmonary ACE activity and capillary surface area during postnatal development. J Appl Physiol 1987;62:2031-41.

19 Schutz S, Le Moullec JM, Corvol P, et al. Early expression of all components of the renin-angiotensin system in human development. Am J Pathol 1996; 149:2067-79.

20 Fogo A, lchikawa L. Renin and angiotensin system in development of mice and men. Am J Pathol 1996; 149:1797-801.

21 Barr M Jr. Teratogen update: angiotensin-converting enzyme inhibitors. Teratology 1994;50:399-409. 